This article was downloaded by: [Memorial University of Newfoundland]

On: 30 January 2015, At: 05:09

Publisher: Routledge

Informa Ltd Registered in England and Wales Registered Number: 1072954

Registered office: Mortimer House, 37-41 Mortimer Street, London W1T

3J H, UK

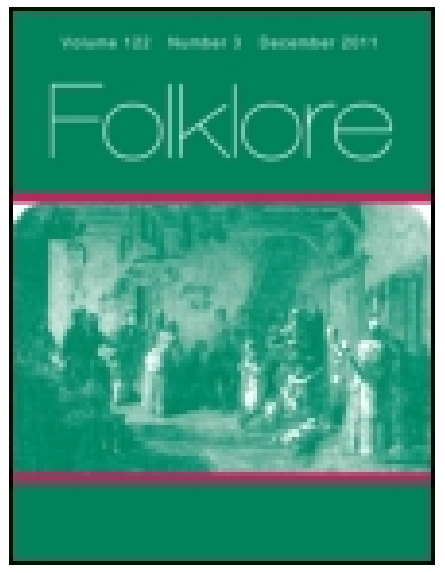

\title{
Folklore
}

Publication details, including instructions for authors and subscription information:

http:// www. tandfonline.com/loi/ rfol20

\section{The Place of Totemism in the Evolution of Religion}

F. B. J evons M.A. LITT.D.

Published online: 14 Feb 2012.

To cite this article: F. B. J evons M.A. LITT.D. (1899) The Place of Totemism in the Evolution of Religion, Folklore, 10:4, 369-383, DOI: 10.1080/0015587X.1899.9720508

To link to this article: http:// dx. doi. org/ 10.1080/ 0015587X. 1899.9720508

\section{PLEASE SCROLL DOWN FOR ARTICLE}

Taylor \& Francis makes every effort to ensure the accuracy of all the information (the "Content") contained in the publications on our platform. However, Taylor \& Francis, our agents, and our licensors make no representations or warranties whatsoever as to the accuracy, completeness, or suitability for any purpose of the Content. Any opinions and views expressed in this publication are the opinions and views of the authors, and are not the views of or endorsed by Taylor \& Francis. The accuracy of the Content should not be relied upon and should be independently verified with primary sources of information. Taylor and Francis shall not be liable for any losses, actions, claims, proceedings, demands, costs, expenses, damages, and other liabilities whatsoever or howsoever caused arising directly or indirectly in connection with, in relation to or arising out of the use of the Content.

This article may be used for research, teaching, and private study purposes. Any substantial or systematic reproduction, redistribution, reselling, loan, sub-licensing, systematic supply, or distribution in any form to anyone is 
expressly forbidden. Terms $\&$ Conditions of access and use can be found at http://www.tandfonline.com/page/terms-and-conditions 


\section{Jjolk= Tore.}

TRANSACTIONS OF THE FOLK-LORE SOCIETY.

\begin{tabular}{|lll}
\hline VoL. X.] & DECEMBER, I899. & [No. IV. \\
\hline
\end{tabular}

\section{THE PLACE OF TOTEMISM IN THE EVOLUTION OF RELIGION.}

BY Ð. B. JEVONs, M.A, ZITT.D.

(Read at Meeting of April 19th, 1899.)

THE question as to the place totemism occupies in the evon lution of religion is one which has of late been exhaustively discussed by M. Marillier in a series of articles, ${ }^{\prime}$ which by their learning, power, and penetration have earned the gratitude, and will always command the respect, of all who are interested in the early history of religion. The question has also been touched on by Professor Tylor," whose lightest word carries with it all the weight which justly attaches to any utterance of one whom we all regard as the most eminent of anthropologists.

I am sorry to say that both writers are of opinion that I have greatly overrated the importance of totemism in the evolution of religion; and conscious though I am of their superior strength, still, when the Folk-Lore Society courteously offered me the opportunity to make reply, I felt that

\footnotetext{
'In the Revue de Cllistoire des Religions, I., vol, xxxvi., no. 2 ; II., vol. xxxvi., no. 3 ; III., vol. xxxvil., no. 2 ; IV., vol. xxxvil., no. 3.

Jowrmal of the Anthropological Institute, vol i. (New Series), pp. 138 . 248.

VOL, $x$.

2 B
} 


\section{0 \\ Totemism in the Evolution of Religion.}

as I still held to my views I was bound to make the best fight that I could for them.

But before beginning the present discussion, I should like to say that the differences between myself and M. Marillier as to the method in which the history of religion should be approached are important enough to deserve a paper to themselves, and that I must reserve them for separate treatment if, peradventure, the Society should be inclined to repeat its invitation.

Thus much premised, I proceed.

To M. Marillier,' the attempt to reduce all forms of plantand animal-worship to totemism seems narrow and inexact. As it is pleasant to begin by agreeing, if possible, with an opponent so courteous as M. Marillier, I am glad to say that to me also the attempt seems both inexact and narrow. But it is an attempt which I have not made. It is one thing to say, as I have said, that the first plants and animals to be worshipped were totems; it is a different thing to say that all the plants and animals which came to be worshipped subsequently in post-totem times were totems, and I have not said it. And so long as the Australian blackman, with his totem-clans, is regarded by anthropologists as occupying the lowest place in the evolution of society, so long will it be a plausible theory that his totem-plants and animals occupy the lowest place in the evolution of religion.

The same misunderstanding gives their point to sundry other criticisms. Now in all cases I should feel that for any misunderstanding of my words I was presumably myself to blame; but when a critic so patient, so tolerant, and so fairminded as M. Marillier misunderstands me, the presumption becomes a certainty. Nevertheless, the fact remains that I am not so totemist as $M$. Marillier paints me. He seems to imagine I hold, or am bound to hold, that every deity began by being a totem; and he has no difficulty in pointing to many deities who probably, or certainly, never were ' Iv., p. 396. 
totems at any time, e.g., deities of the sea, lakes, rivers, fountains, sun, moon, stars, wind, earth, and sky. ${ }^{1}$

Now I might reply that all the natural objects enumerated by M. Marillier do, as a matter of fact, actually occur within our knowledge as totems ; ${ }^{2}$ but I shall not, because then it might be inferred that in my opinion wherever the sun, for instance, was worshipped as a deity he must previously have been venerated as a totem. That is not my opinion. What I have maintained, and do maintain, is that if a community, already having one or more gods, wishes for any reason to add another to its collection, it will probably proceed to worship the new one with a ritual similar to that with which it worships its old-established gods. If the community in question is a totem-clan, the new-comer will be assimilated to the totem-system; if it has passed out of the totem-stage, it will straightway erect the new-comer into a tribal, or local, or national deity, as the case may be, and then we shall have an instance of a nature-power made into a god without ever having served as a totem. The vast majority of the gods known to the antique religions and to savage races may thus have originated in post-totem times, and never have been themselves totems. I submit, therefore, that there is no narrowness in this view. As to its inexactness, I can only say on the one hand that M. Marillier himself conjectures that the sacred cattle of the Damara clans have been assimilated to pre-existing totems, which they have driven out, ${ }^{3}$ and on the other that both M. Marillier and Professor Tylor" fully admit "the. immense influence of sacrificial feasts as means of binding societies of worshippers together and to their common divinity."

It is now, I imagine, almost superfluous for me to say

II, p. 221 ; lli., pp, 224, 226; iv., pp. 397, 402.

- Frazer, Totemism, pp. 24 and 25.

- III., p. 232.

- Jowrnal of the Anthrofological Institute, vol. I. (New Series), p. 145. 


\section{Totemism in the Evolution of Religion.}

that I do not hold that the mere anointing of an altar-post ${ }^{1}$ proves the deity thus worshipped to have been originally a totem, or that the sacramental meal and the social institutions of totemism are so "mutually dependent" 2 that the one cannot exist without the other. On the contrary, I have argued that the sacrificial feast is used by all sorts of societies as a means of binding themselves to their divinity - voluntary associations as well as blood-relations, memhers of a nation or a tribe as well as members of a totemclan. And, once more, so long as the totem-clan is the earliest social organisation known in the evolution of society, so long will those who believe in the correlation of social and religious evolution look to the totem-clan as the earliest society of which the members could habitually worship a common deity.

But though I am ready to admit, and even to insist, that very few of the deities known to us are transfigured totems, still my argument does require me to maintain that a totemplant or animal may under stress of circumstances develop into a non-totem deity. Whether $M$. Marillier does or does not consider this process of evolution possible, I cannot quite make out. If he argues that a clan-totem is not a tribal deity, I quite agree. If he argues that a divine animal by the very fact that it becomes a tribal deity ceases to be merely the totem of one particular clan of the tribe, I agree again. And if he admits, as he seems to do, that an animal which originally was a clan-totem may become the deity of a whole tribe, then that is all I want. It is possible for a clan-totem to evolve into a tribal deity; and the fact that in so evolving it ceases to be a totem is not, as M. Marillier strangely seems to imagine, an argument

'M. Marillier, III., p. 226.

* Jbid., p. 230.

- I., p. 229.

- I., p. $23 \mathrm{r}$.

'I., p. 247 . 
against my theory, ${ }^{1}$ but is itself the theory which 1 am seeking to maintain.

Whether the totemistic organisation of society is or is not a necessary stage in the evolution of society, is a question which is primarily one for sociologists to decide. But it is also one in which historians of religion have an interest; and it is remarkable that both Professor Tylor and M. Marillier have so little to say about it. The former allows it "far greater importance in sociology than in religion;" the latter admits casually that totemist institutions are to be found everywhere, but does not anywhere think it necessary to answer, or even to ask the question, whether they are a necessary phase of social evolution. Yet it would dispose finally of the religious importance of totemism, if it could be shown that there was no reason to regard it as a necessary stage in the evolution of society. I propose, therefore, to take judgment by default, and to regard the social necessity and importance of totemism as conceded. I think I may fairly say that by most sociologists it is assumed.

Now if totemism, as a form of social organisation, is thus necessary and has thus been universal, I submit that as a form of religious organisation it cannot be dismissed as of secondary importance to theology, and that there is nothing narrow in the attempt to fix the relation in which it stands to other and historically later forms of religious organisation. Professor Tylor speaks of "the ancient and powerful action of the totems at once in consolidating clans and allying them together within the larger circle of the tribe," and he says "this may well have been amongst the most effective processes in the early social growth of the human race." " Yet

'The possessive pronoun here and elsewhere must not be taken to mean that I claim the theory, or whatever it is, as my own invention, but simply that I am interested in arguing on behalf of the theory.

"Sournal of the Anthropological Strstitute, bec. cith, P. 144.

Thid.

- Bid., p. 543 . 


\section{Totemism in the Evolution of Religion.}

he has previously said: "the importance belonging to totem animals as friends or enemies of man is insignificant in comparison with that of ghosts or demons." Surely, we may ask him, what equally "effective process" the belief in ghosts or demons has produced in "early social growth"? If totems had a power so great, can they have been so utterly insignificant as "friends or enemies of man"? And are we to deny all correlation between social and religious evolution? I am aware that M. Marillier denies ${ }^{1}$ that clantotems are either regarded as divine or worshipped; but even he admits that the redskin offers sacrifice to his individual totem; while Professor Tylor, in his article on totemposts, says both that the Killer-whale is a totem "belonging to the Haida-Tsimshian group of tribes," and that "the Killer-whale or Skana is a great spiritual being to the Haida-Tsimshian tribes, who worship and pray to it, blending in their ideas the actual animal and the demon Skana embodied in it." But as Professor Tylor, when he is making "Remarks on Totemism, with especial reference to some modern theories respecting it," says that the totemgod is "a merely hypothetical being," " I will not venture to infer that a totem who is a great spiritual being, worshipped and prayed to, is a totem-god, for, if I did, I might expose my ignorance of the difference between such a spiritual being and a totem-god.

I will therefore retreat on to what is, I hope, safer ground. Unless we are to divorce economics as well as theology from sociology, we may, I trust, regard the "ancient and powerful action of the totems " on social evolution as constituting a presumption that totemism may have had some economic effects of its own. One of the most important steps in economic evolution undoubtedly was the domestication of animals. We have only to contrast the condition of those

\footnotetext{
'II., 1.' 364 .

"Jourmal of the Anthropological Institute, lat, cit., p. 136.

"lbic., p. 145 .
} 
savages who have no domestic animals with the civilisation or semi-civilisation which follows in the train of domestication to see that. Now the respect (whether religious or merely social) which is usually shown to the totem-animal is such that any animal capable of domestication would, in the course of generations, become tame under it. Thus, totemism merely as a social institution would naturally and inevitably result in the eventual domestication of those totem-animals which happened to be domesticable, the others would naturally remain wild. Those totem-clans which had been lucky in this lottery would find thenselves the owners of a valuable economic possession, a fresh source of motive power, such as the horse or camel, or a permanent food-supply in the form of cows or sheep. The lucky clans would increase and multiply at the expense of the less fortunate-the bulls at the cost of the bears-until the community which had originally consisted of different totem. clans would come to be a tribe in which such distinctions were either not recognised at all or survived only in relatively unimportant customs. In a word, the economic revolution produced by domestication would entail a social revolution also, and lead to the destruction of the totemistic form of social organisation.

But of all this 1 am not fortunate enough to convince M. Marillier. As a cause of domestication, he considers totemism at once inadequate and superfluous. He regards it as inadequate because a totem-animal, though respected and spared by the human members of its own clan, is neither respected nor spared by any other clan of the same community, and therefore does not get the chance of growing tame. But this objection is a weapon with two edges, if not more. As Professor Tylor has pointed out, it tells against the Wilken-Frazer theory (adopted by M. Marillier) that a totem-animal is the receptacle of a totemist's "external soul "; for the wife who kills her husband's totem is in danger of destroying her husband's life. It tells also, $\mathfrak{I}$ 
think, against the theory of totemism which Professor Tylor himself is inclined to adopt, namely that the soul of a man, at death, migrates into some animal, which then becomes totem and taboo to his descendants; for a man's children do not belong to his totem-clan but to their mother's, and thus are at liberty to kill his totem-animal and make things uncomfortable for his migrated soul. I suggest, therefore, that though $I$, being a totemist, am theoretically at liberty to kill my father's totem-animal, or my wife's, still, as a matter of fact and for reasons which I sum up in the phrase "for the sake of peace and quietness," I usually abstain from thus provoking parental castigation or marital disagreements-especially if I have several wives. In fine, it must not be forgotten, though Professor Tylor and M. Marillier seem to forget, that though I may at my own risk kill another man's totem, the totem's clan are entitled to claim compensation, and will certainly exact vengeance from me. The protection thus afforded by the clan-taboo and the public opinion of the tribe is, I submit, all that is required for the domestication of any domesticable animal.

Important economically as is the domestication of animals, it is a step which has not been universally taken-there are savages still which possess no domestic animals. What then is the reason, especially if totemism, as a social institution, has been universal? The reason is simple: not all species of animals are capable of domestication. Where there were no domesticable animals, there no animals could be domesticated, and man consequently never got beyond the stage of totemism. There are two areas of the earth's surface in which no domesticable species occur: North America and Australia. And they are precisely the two areas in which totemism prevailed until the coming of European man. It is to them, therefore, that we must look, if we wish to understand the condition of man in the pre-pastoral period-in the time when he had not yet 
domesticated any animal. It is to them also that I turn for a refutation of $\mathrm{M}$. Marillier's position that totemism as a cause of domestication is superfluous. For domestication, according to M. Marillier, all that is required is that an animal should be considered divine and treated as sacred by the inhabitants of the district ${ }^{1}$ it is not necessary that it should be a totem. I quite agree that an animal will become tame if treated as divine or sacred; but I look round the two totem-areas, the homes of the Redskin and the Australian blackfellow, and I ask myself, Where are there any animals, except totem-animals, which are treated as sacred or divine? Why should we invoke divine animals which are not totems to account for domestication, when there are already totem-animals all over the world ready and able to do the work?

But, says M. Marillier, domestic animals are rarely, if indeed ever, found as totems. ${ }^{2}$ Well, in the two areas of North America and Australia, of course, they could not be, because there are not any. In Europe and Asia, totemism is a stage of social evolution too long past for us to find anything but survivals. And when in Africa, amongst the Damaras, we do come across the domestic cow looking, as M. Marillier admits, ${ }^{8}$ very like a totem, M. Marillier says -e mera conjectura-that in this case the cattle are probably not totems, but have taken the place of the real original totem-animals.

On one point, however-and not only one point I am happy to say-M. Marillier and I are agreed. It is that originally domesticable animals (whether they were totems or not) were not eaten, or only in a ritual way; and it was but gradually and by very slow degrees that they came to be eaten commonly and non-ritually. I wish to point out that the same thing happens with animals that certainly are

III., p. 367.

III., p. 228.

1., p. 232. 


\section{Totemism in the Evolution of Religion.}

totems. The witchetty grub, for instance, is a totem, and has come to be commonly eaten by the Aruntas. ${ }^{.}$But the existence of large numbers of wholly inedible totems forbids us supposing that animals are chosen as totems because they are good to eat. We must then suppose that the taboo on the grub as food broke down under the discovery that the grub as food was good. Amongst the Amazulu, cattle might only be eaten as a religious exercise, with the result that the devotion to that particular article of religion became excessive: the pious were always mortifying themselves by a beef diet. Is it an unreasonably wild surmise that the witchetty grub also may originally have been eaten only ceremonially? In other words, is the "totem sacrament" scientifically a wholly inadmissible hypothesis?

That sacrificial feasts are of immense importance as a means of binding worshippers to their god is admitted by Professor Tylor. That ritual immolation and the sacramental meal are especially intimately connected with the sanctity of domesticated animals is admitted, or rather insisted upon, by M. Marillier. That such rites go back to times when the animals in question were rather domesticable than as yet domesticated seems also to be conceded. But at that time the animals were, I submit, totems.

What more is required, I will not say to make the totemsacrament admissible as a hypothesis, but to prove it as a fact? Is it alleged that a totem cannot be a god? The Killer-whale is, if not a god, a great spiritual being, worshipped and prayed to. Is it that a totem-clan cannot eat its totem? 'The Aruntas eat their witchetty grub. Is it that the ritual immolation and sacramental eating of the totem-animal is purely hypothetical? I have from the first proclaimed that the assumption was but a working hypothesis," and I do not claim anything more for it now.

1 Horm Sciontific Expedition, pt. iv., p. $176 \mathrm{ff}$.

" History of Keligions, p. 156. "Wo must regard it mocely as a working hypothesis that in pre-pastoral times the animal sacrificed and eaten by the totem clan was the totem animal." 
Indeed, I am wondering whether I can claim as much, for Professor Tylor seems to think that a hypothesis is inadmissible till it is proved-which would rule all hypotheses whatever out of court. "Till the totem sacrament," he says, "is vouched for by some more real proof it had better fall out of speculative theology." But if theology only admitted things which were already proved, it would no longer be speculative, if theology. I fear it would cease even to be progressive, and I am sure it would be very dull.

At the time when the above paper was written, I had not seen Messrs. Spencer and Gillen's Native Tribes of Central Australia; but by the courtesy of the editor I am now allowed to add by way of postscript a few remarks on the light thrown on the subject of totemism by the publication of that valuable contribution to anthropology. To some extent it has eclipsed the gaiety of theology by converting the "totem-sacrament" from an engaging hypothesis into a sober fact, a fact which perhaps after all "had better" not "fall out of speculative theology."

The discovery of this striking testimony to the genius, and the accuracy of the late Professor Robertson Smith's scientific imagination, not only shows that science would be the poorer if some or all hypotheses were ruled out of court, it changes the conditions under which the place of totemism in the evolution of religion must be discussed. As long as the totem-sacrament was a pure hypothesis, the only way in default of the direct evidence, which has now turned up, was to cast about for everything which might be regarded as a survival of it, or an indication of its previous existence. The obvious method of meeting this line of argument, and a method largely employed by M. Marillier, was to appeal to the "plurality of causes," and to point out that the supposed effects of totemism might quite well be due to other causes, and that consequently we must, if we wish to be scientific, build on those other causes known to exist, and not on such 


\section{Totemism in the Evolution of Religion.}

an unproved hypothesis and mere conjecture as the "totemsacrament." To clinch the matter, M. Marillier also adds many ingenious (and a priori) arguments to show that certain alleged survivals cannot possibly be survivals of totemism, that totemism cannot pass into any other form of religion, and that the sacramental meal cannot be regarded as going back beyond the pastoral to the totemistic stage of social evolution. In fine, the totem-sacrament was a superfluous and gratuitous supposition, and there were many other hypotheses by which its supposed effects could be explained or explained away.

Now, however, thanks to Messrs. Spencer and Gillen, things are changed. It is no longer necessary to argue that totemism must have been a stage in the evolution of religion, it is an established fact that it was. Arguments to show that the totem-sacrament cannot have existed, and that its existence is a superfluous hypothesis have themselves become gratuitous. Arguments to show that, if we confine ourselves to actual objective facts, we must say that the sacramental meal is only found in connection with pastoral cults, are now seen to prove only that the sacramental meal had not been found amongst totemists, not that it never existed amongst them.

With regard to alleged survivals of totemism, the question whether they are survivals will henceforward have to be argued on its merits. It can no longer be ruled out of court on the ground that the totem-sacrament is a mere piece of speculative theology. It is to this discussion, and to the light thrown on it by The Native Tribes of Central Australia, that I should like to make bricf reference here, especially as it is bound up with the further important question whether it really is, as alleged by M. Marillier, impossible for totemism to pass into some other form of religion.

By a "survival" of totemism is meant that some rite, or institution, or other feature of totemism continues to exist amongst a people who have once been, but no longer are, 
totemists. Thus, for instance, self-mutilations, originally designed to make the worshipper resemble his totem in some respect, might continue to be practised even when the people in question had ceased to be totemistic in their social organisation. Worship of the totem-animal might continue even when the animal had ceased to be the totem of a particular totem-clan, and had come to be a tribal deity sacred to all members of the tribe, no matter what clans they belonged to. Now M. Marillier repeatedly argues that various alleged survivals cannot possibly be survivals of totemism, because they are practised by the whole of the tribe in which they are found to exist, and not by one particular clan. To this I believe that $I$ am fully entitled to reply that if such rites, \&c., were still practised by a totemclan they would not be survivals of totemism, they would be totemism itself. The very term "survival" implies that the clan-organisation has given way to some other form of social structure. But so firmly is M. Marillier resolved not to admit the possibility of any transition from totemism to any other stage of religious evolution, that he does not see that he is paying himself with mere words. He lays it down that a totem-deity is one worshipped by a totem-clan, a tribal deity one that is worshipped by a whole tribe, that if an animal sacred to one clan comes to be sacred to the whole tribe, it thereby ceases to be a totem; therefore, no totem can be a tribal deity; as long as it is a totem it cannot be a tribal deity; when it becomes a tribal deity it is not a totem. But this does not in the least show that an animal might not in the course of its history first be a totem and then be a tribal deity-first be worshipped by one clan and then by the whole tribe. However, to M. Marillier "the transformation of cults limited to a totem-clan into cults common to a tribe is unintelligible." "Nothing," he says, "nothing essential to totemism can remain in a religion which has passed beyond the bounds of the totem-clan." And he has ingenious a priori arguments to show that it 


\section{Totemism in the Evolution of Religion.}

is impossible for the whole of a tribe to participate in the cult of one and the same totem.

M. Marillier, farther, believing in animal-worship, and not believing in totemism, as a necessary stage in the evolution of religion, is very firm in his demand for evidence that a totem is ever the object of a "cult" in the proper sense of the term: the mere respect which, when shown to a non-totem animal, is sufficient evidence to raise animal-worship to a cult, does not suffice, when paid to a totem-animal, to convince $M$. Marillier that the totem is the object of a veritable cult. The extremely elaborate rites and ceremonies, however, which Messrs. Spencer and Cillen's tribes spend weeks and months in celebrating with the most meticulous care and the profoundest reverence, will, I trust, amount to the dimensions of a cult in M. Marillier's eyes. If they do, he will discover this remarkable fact: that the whole of the tribe, without regard to totem-clans, are present at the celebration of each and every totem-rite and cult. Not only so, but any member of the tribe may by invitation be the celebrant of any rite, and "need not of necessity belong to the totem with which the ceremony is concerned." In fact the various clans which compose the tribe have come to "pool" the whole of their cults. Thus we have the very state of things which M. Marillier pronounces unintelligible and impossible: a cult which originally belonged to one particular clan is thrown open to the whole tribe; in M. Marillier's words, "a cult limited to a totem-clan is transformed into a cult common to a tribe;" it has "passed beyond the bounds of the totemclan." Will M. Marillier say that "nothing essential to totemism remains" in it ?

It is obvious that in these Engwura ceremonies we have the results of a process analogous to that by which in more developed societies a pantheon is produced-only we have in place of a pantheon what perhaps I may call a "pantotemeion." The transition from totemism, as it is known 
elsewhere, to polytheism is here more than half accomplished. Holy ground, such as may become the sacred enclosure or temenos of god and temple, is to be found round the Ertnatulunga; sacred objects, to which myths of all kinds hereafter may attach, are provided in the Churinga; sacred ceremonies, the meaning of which is already forgotten but the outlines of which already provide a fixed, public ritual for the whole community, are forthcoming in the Engwura; the sacramental meal is there in the Intichiuma ceremonies; and the germs of a hereditary priesthood may be found in the fact that the Intichiuma may only be celebrated by the clan of the particular totem concerned, though the whole tribal community (without reference to clans) is admitted to eat the sacred food, after the celebrant has first partaken of it.

\section{WEDNESDAY, MAY 17th, 1899.}

Tine President (Mr. E. Sidney Hartland) in the Chair.

Tur minutes of the last Meeting were read and confirmed.

The election of Mr. D. Isaac and Mr. C. H. James was announced. The resignation of Miss Edith Mendham and Mr. J. T. Naaké, and the death of Lady Paget were also announced.

Lieut.-Colonel Temple read a paper entitled "The Machinery of Folktales as exhibited in the Legends of the Panjab," and a discussion followed, in which Mr. Coldstream, Mr. Crooke, the Rev. H. N. Hutchinson, Mr. Clodd, Miss Dempster, and Mr. Nutt took part.

The meeting concluded with a vote of thanks to Colonel Temple for his paper. 